\title{
Wakaf Saham Sebagai Alternatif Wakaf Produktif Pada Perkembangan Ekonomi Syariah di Indonesia
}

\author{
Dini Selasi ${ }^{1}$, Muzayyanah ${ }^{2}$ \\ Sekolah Tinggi Ma'had Ali Cirebon (STAIMA) ${ }^{1}$, Universitas \\ Muhammadiyah Cirebon (UMC) ${ }^{2}$ \\ diniselasi1980@gmail.com ${ }^{1}$, muzayyanah@umc.ac.id ${ }^{2}$
}

\begin{abstract}
Share waqf is a type of productive waqf that is currently in demand by the public with systems and mechanisms that make it easier for Islamic stock investors to donate waqf. The qualitative research method uses a phenomenological approach, where significant statements, structural and textual descriptions, data sources are carried out by interviews, using documents, and observation. The result of this journal is that $A B$ SOTS already has a share waqf facility where the wakif of the temporary sharia stock investors who become the object or mauqif are sharia stocks that are included in the DES list and their nadzir or those who manage BWI stock waqf or dhuafa's wallet which will distribute to mauquf' alaihi as the beneficiary of the mauqif.
\end{abstract}

Keywords; waqf, Islamic stocks, productive waqf

\begin{abstract}
Abstrak
Wakaf saham merupakan jenis wakaf produktif yang sedang diminati oleh masyarakat dengan sistem dan mekanisme yang memudahkan para investor saham syariah untuk berwakaf. Metode penelitian kualitatif dengan pendekatan fenomenologi, dimana pernyataan signifikan, deskripsi struktural dan tekstual, sumber data dilakukan dengan wawancara, menggunakan dokumen, observasi. Hasil dari jurnal ini adalah para AB SOTS sudah memiliki fasilitas wakaf saham dimana wakifnya para investor saham syariah sementara yang menjadi objek atau mauqif adalah saham syariah yang masuk dalam daftar DES dan nadzirnya atau yang mengelola wakaf saham BWI atau dompet dhuafa yang akan menyalurkan pada mauquf'alaihi sebagai penerima manfaat mauqif.
\end{abstract}

Kata kunci; wakaf, saham syariah, wakaf produktif

\section{PENDAHULUAN}

Kegiatan ekonomi dalam Islam sudah diatur dalam kajian hukum Islam dimana penerapannya terbagi dalam hukum Islam yang bersifat tetap dan tidak berubah berdasarkan nash qath'i kemudian hukum islam yang fleksibel yang banyak ditemukan dalam ekonomi Islam yang didasarkan pada hasil ijtihad yang sudah diterapkan sejak zaman Rasullulah (Ridwan, 2018).

Perkembangan ekuitas di pasar modal Syariah sangat pesat, berawal dari pendirian pasar modal Syariah pada tahun 1997 yang telah diterbitkan oleh Danareksa Invesment Management (DIM), maka di 2000 di mana DIM bekerjasama dengan Indonesia bursa efek (BEI) menerbitkan indeks Islam Jakarta (JII) yang merupakan indeks untuk saham Syariah 
yang berjumlah 30 Syariah hingga saat ini pembangunan sangat baik bahkan terus mengejar eksistensi saham konvensional yang jauh lebih berkembang terlebih dahulu. Banyak fatwa, peraturan dan aturan yang telah tersedia tentang pasar modal Syariah, terutama tentang saham Syariah (Hana, 2018).

Saham Syariah ini memiliki beberapa keunggulan sehingga banyak masyarakat mulai merasakan manfaat saham Syariah ini (Ulinnuha, Susilowati, \& Hana, 2020). Dalam perkembangan masyarakat telah mulai bergeser dari sesuatu yang konvensional ke arah yang didasarkan pada Syariah Islam. Banyak orang yang mulai bermigrasi, tidak hanya dalam gaun (Hijab yang sudah banyak), kebanyakan yang mempelajari kehidupan Islan Syariah dan juga pemenuhan kebutuhan hidup mereka, seperti belajar Verity menurut Syariah Islam. Dalam hal ini, masyarakat mulai melakukan semuanya berdasarkan hukum Islam, termasuk para investor saham .

Dalam pengembangan investasi ekuitas Syariah, kini telah diperkenalkan adanya saham Wakaf yang tentunya diwakili adalah saham menurut Syariah Islam. Saham yang diwakili harus tercantum dalam daftar sekuritas Syariah atau DES yang dikeluarkan oleh otoritas Jasa Keuangan (OJK). Daftar saham yang tertera pada daftar efek Syariah (DES) disaring dan dipilih setiap enam bulan atau dalam kurun waktu satu tahun dari daftar daftar efek Syariah (DES) yang berbeda dari setiap semester, jika pada semester 1 dari daftar daftar efek Syariah (DES) belum tentu pada semester 2 akan dimasukkan kembali, hal ini dikarenakan jika perusahaan yang terdaftar di Bursa tidak memenuhi syarat sebagai saham Syariah maka secara otomatis dihapus dari Daftar efek Syariah (DES) (Hana, 2019). Saham Wakaf sudah mulai diluncurkan saat ini, sehingga masyarakat mulai dapat mewakili sahamnya dengan mudah dimana saja dan kapan saja dipersenjatai dengan kemajuan teknologi saat ini. Wakaf adalah pengalihan hak pribadi milik suatu badan yang akan menguntungkan masyarakat (sholihin, 2010).

Lahirnya UU Republik Indonesia No. 41 tahun 2004 tentang Wakaf diarahkan untuk memberdayakan Wakaf yang merupakan salah satu instrumen dalam membangun kehidupan sosial ekonomi umat Islam. Keberadaan hukum Wakaf ini menjadi momentum pemberdayaan Wakaf dengan cara yang produktif, karena didalamnya terdapat pemahaman dan pola manajemen yang komprehensif dari potensi wakaf modern. UU Republik Indonesia No. 41 tahun 2004 tentang Wakaf tidak memasukkan harta yang bergerak atau bergerak, termasuk Wakaf uang yang banyak digunakan, tidak terbatas pada pendirian tempat ibadah keagamaan dan sosial. Formulasi hukum seperti itu, jelas perubahan yang sangat revolusioner dan jika dapat diwujudkan akan memiliki beberapa 
konsekuensi atau efek Multiplier, terutama dalam kaitannya dengan pemberdayaan ekonomi umat Islam (Medias, 2010).

Dalam kajian ini, penulis akan meneliti bagaimana mekanisme Wakaf saham sebagai Wakaf produktif dalam pengembangan ekonomi Syariah di Indonesia. Dengan perkembangan saham di pasar saham Syariah Indonesia memperkenalkan adanya saham Wakaf Syariah, penulis berusaha melakukan pengembangan Wakaf saham Indonesia mulai dari dasar hukum Wakaf sampai dengan apa yang menjadi saham Wakaf hingga perkembangannya secara umum.Tujuan dari penelitian ini adalah mengenalkan model wakaf produktif selain yang kita kenal secara umum misalnya pemanfaatan wakaf uang namun dengan penelitian ini dikenalkan adanya wakaf saham yang bisa dimanfaatkan defidennya atau keuntungannya untuk kesejahteraan umat memalui lembaga terkait seperti Badan Wakaf Indonesia, Dompet Dhuafa dan lainnya.

\section{KAJIAN LITERATUR}

Menurut Ahyudin sebagai Presiden Gobal Islamic Philantropy, kebutuhan masyarakat saat ini tidak lagi terbatas pada praktik zakat, infak, dan sedekah. Lebih dari itu, problematika umat membutuhkan praktik wakaf yang luas. "Wakaf tidak hanya menebarkan maslahat luas dan menjadi solusi bagi masalah kesejahteraan umat. Wakaf juga menjadi cara umat Islam untuk mengabadikan hartanya hingga ke akhirat," tambahnya. Dalam diskusi forum tersebut, dijelaskan pula bagaimana wakaf produktif mampu menjadi energi atau penggerak produktivitas umat. "Umat Islam belum dikatakan hebat jika belum 'melepaskan' hartanya dan membawanya ke akhirat. Bagaimana caranya? Wakaf." kata Ahyudin (Ahyudin, 2017).

Dalam etimologi bahasa Wakaf "Waqf" yang berarti "al-Habs". Artinya: menahan, berhenti, atau diam. [Ibnu Manzhur: 9/359]. Penahanan hak milik atas materi benda (al-'ain) untuk tujuan menyedekahkan manfaat atau faedahnya (al-manfa'ah) [al-Jurjani: 328] Menahan asal harta (tanah) dan menyedekahkan manfaat yang dihasilkan (Ibnu Qudamah: 6/185). Kata Wakaf Secara Etimilogis berasal dari kata waqafa-yaqifu-waqfan yang mempunyai arti menghentikan atau menahan. atau berdiam di tempat atau tetap berdiri (mysharing.co, 2017).

Definisi dan Unsur Wakaf Sesuai UU No. 41 Tahun 2004 \& PP No. 42 Tahun 2006, Tentang Wakaf (Teguh Saptono, 2019).

a. Wakaf; Perbuatan hukum wakif untuk memisahkan dan/atau menyerahkan sebagian harta benda miliknya untuk dimanfaatkan selamanya atau untuk jangka waktu tertentu sesuai dengan kepentingannya guna keperluan ibadah dan/atau kesejahteraan umum menurut syariah. 
b. Benda Wakaf; Harta benda yang memiliki daya tahan lama dan/atau manfaat jangka panjang serta mempunyai nilai ekonomi menurut syariah yang diwakafkan oleh Wakif

c. Wakif; Pihak yang mewakafkan harta benda miliknya.

d. Nazhir; Pihak yang menerima harta benda wakaf dari Wakif untuk dikelola dan dikembangkan sesuai dengan peruntukannya.

e. Ikrar Wakaf; Pernyataan kehendak wakif yang diucapkan secara lisan dan/atau tulisan kepada Nazhir untuk mewakafkan harta benda miliknya.

f. Mauquf 'Alaih; Penerima manfaat benda wakaf

\section{Dasar hukum Wakaf}

a. Menurut Al-Qur'an

- "Kamu sekali-kali tidak sampai kepada kebajikan (yang sempurna), sebelum kamu menafkahkan sehahagian harta yang kamu cintai. Dan apa saja yang kamu nafkahkan maka sesungguhnya Allah mengetahuinya." QS.Ali Imran ; 92

Maka Abu Thalhah bergegas menghadap Rasulullah saw dan menyatakan, "Sesunguhnya harta yang paling kusayangi ialah hartaku di Bairuha dan hartaku di Bairuha itulah yang kuwakafkan di jalan Allah SWT. Itulah yang menjadikan QS Ali Imran (3) ayat 92 ini menjadi landasan disyariatkannya berwakaf (Purnomo, 2019).

- "Hai orang-orang yang beriman, nafkahkanlah (di jalan Allah) sebagian dari hasil usahamu yang baik-baik dan sebagian dari apa yang kami keluarkan dari bumi untuk kamu, dan janganlah kamu memilih yang buruk-buruk lalu kamu menafkahkan daripadanya, padahal kamu sendiri tidak mau mengambilnya melainkan dengan memincingkan mata terhadapnya, dan ketahuilah bahwa Allah Maha Kaya lagi Maha Terpuji" QS.Al Baqarah ; 276.

- "Perumpamaan nafkah (yang dikeluarkan oleh) orang-orang yang menafkahkan hartanya di jalan Allah adalah serupa dengan sebutir benih yang menumbuhkan tujuh bulir, pada tiap-tiap bulir seratus biji. Allah meipatgandakan (ganjaran) bagi siapa yang Dia kehendaki, dan Allah Maha Luas (karunia-Nya) lagi Maha mengetahui" ( QS. Al Baqarah; 261)

b. Hadits

- Wakaf ini menjadi sedekah jariyah sebagaimana hadis Rasulullah SAW, "Jika anak Adam meninggal maka terputuslah amalnya kecuali tiga perkara, yaitu sedekah jariyah, ilmu yang diambil manfaatnya, anak saleh yang selalu mendoakan orang tuanya." (HR Muslim). Dan hadis Rasulullah SAW, "Tahan pokoknya dan salurkan hasilnya." (HR Bukhari Muslim).

c. Wakaf saham diihat dari ilmu fiqih 
Menurut Dr. Oni Sahroni (Anggota Dewan Syariah Nasional Majelis Ulama Indonesia) dalam tulisannya pada Republika.co.id (Sahroni, 2018) menerangkan wakaf saham dalam tinjauan fiqih; wakaf saham itu dibolehkan dalam Islam dengan syarat saham yang diwakafkan itu saham syariah (yang memiliki underlying asset yang halal) sesuai peraturan perundang-undangan, dilakukan istibdal, dan saham yang diwakafkan itu jelas objek dan nilainya. Kesimpulan hukum ini berdasarkan telaah terhadap keputusan Standar Syariah Internasional AAOIFI tentang wakaf saham, regulasi, dan peraturan perundang-undangan tentang wakaf, Fatwa Dewan Syariah nasional MUI tentang saham, dan literatur fikih turats tentang wakaf.

1. Saham yang diwakafkan adalah saham syariah. Saham sebagaimana tersebut itu halal sesuai Fatwa DSN MUI No 40/DSN-MUI/X/2002 tentang Pasar Modal dan Pedoman Umum Penerapan Prinsip Syariah di Bidang Pasar Modal dan Standar Syariah Internasional. Hal yang sama ditegaskan oleh regulasi bahwa saham tidak bertentangan dengan prinsip syariah karena saham merupakan surat berharga bukti penyertaan modal dari investor kepada perusahaan yang kemudian investor akan mendapatkan bagi hasil berupa dividen (Hana, 2018). Konsep penyertaan modal dengan hak bagi hasil usaha ini merupakan konsep yang tidak bertentangan dengan prinsip syariah atau kegiatan musyarakah/syirkah. Jika underlying asset saham tersebut itu halal, mewakafkan saham tersebut itu berarti mewakafkan aset yang halal layaknya mewakafkan aset-aset yang bergerak atau tidak bergerak yang halal dan murah.

2. Saham yang diwakafkan itu jelas objek dan nilainya. Misalnya, mewakafkan berapa lembar saham, nilainya, dan termasuk apakah yang diwakafkan itu sahamnya atau hanya manfaat (benefit) sahamnya, masing-masing memiliki konsekuensi hukumnya.

3. Sejak diwakafkan, saham tersebut itu dimiliki oleh mustahik yang dikuasakan kepada nazir untuk dikelola, sehingga menghasilkan manfaat yang diperuntukkan bagi mustahik.

4. Istibdal terhadap saham jika sudah selesai masa investasinya. Maksudnya adalah mengubah aset wakaf dengan cara dijual atau ditukar dengan aset lain sebagai pengganti karena ada maslahat wakaf.

Wakaf saham tersebut dibolehkan menurut Standar Syariah Internasional AAOIFI yang menegaskan, wakaf saham dan sukuk investasi diperbolehkan dengan catatan pada saat tashfiyah, dilakukan istibdal. Selanjutnya, manfat wakaf (hasil investasi saham) disalurkan kepada penerima manfaat wakaf. Menurut Standar Syariah AAOIFI, landasan bolehnya wakaf saham merujuk pada bolehnya wakaf uang. Standar tersebut menyebutkan, landasan bolehnya wakaf uang 
adalah karena wakaf uang itu sebagai induk hukum (ashl). Pendapat ini adalah pendapat Muhammad bin Abdullah Al-Anshari, sahabat Imam Zufar yang dipilih oleh Imam ibn Taimiyah. Kesimpulan yang sama terjadi pada wakaf saham dan sukuk.

Al-Quran dan Sunnah tidak secara tegas membicarakan hukum wakaf, dan memang kebanyakan hukum wakaf dihasilkan lewat ijtihad dan ini membuat hukum wakaf berkembang sesuai dengan perkembangan zaman. Wakaf dalam bentuk konvensional hanya terbatas pada benda yang tidak bergerak, namun berdasarkan asas manfaat yang ingin disebarkan lewat wakaf ini, banyak obyek-obyek wakaf yang baru seperti halnya wakaf saham, wakaf jasa, wakaf ilmu dan ini tidak bertentangan dengan dasardasar hukum wakaf. Berkembangnya wakaf dapat dijadikan stimulus tumbuhkembangnya perekonomian kaum muslim. Wakaf saham merupakan terobosan baru dalam perwakafan dan manfaat yang dihasilkan dari wakaf ini juga sangat besar. Karenanya wakaf dengan saham merupakan hal yang diperbolehkan (Hanna, 2015).

\section{METODE PENELITIAN}

Penelitian ini menggunakan metode penelitian kualitatif dengan pendekatan fenomenologi, dimana pernyataan signifikan, deskripsi struktural dan tekstual, sumber data dilakukan dengan wawancara, menggunakan dokumen, observasi dan seni dengan berusaha menjelaskan secara rasional, menggunakan asumsi dan data pendukung yang berkaitan dengan penelitian ini (Creswell, 2018). Penelitian ini menggunakan sumber data yang berasal dari jurnal ilmiah, thesis, kegiatan seminar dan dokumen-dokumen yang berkaitan dengan penelitian ini yang dapat menjelaskan secara rasional sesuai dengan fenomena yang terjadi pada para investor syariah.

\section{PEMBAHASAN}

\section{Saham Syariah}

Saham syariah adalah efek berbasis ekuitas yang memenuhi prinsip Islam. objek transaksinya saham syariah adalah kepemilikan perusahaan. Hubungan antara investor dan perusahaan penerbit saham (emiten) adalah hubungan kepemilikan sehingga invetsor adalah pemilik saham dari perusahaan tersebut. Penerbitan saham syariah akan berdampak terhadap komposisi pemegang saham perusahaan. Persentase kepemilikan perusahaan oleh investor ditunjukkan oleh saham yang dimilikinya (Abdalloh, 2018).

Meskipun fatwa sifatnya tidak mengikat, tetapi pada prakteknya fatwa DSN-MUI adalah salah satu rujukan dalam mengembangkan pasar modal syariah Indonesia. Sampai dengan saat ini, terdapat 17 fatwa DSN- 
Wakaf Saham Sebagai Alternatif Wakaf Produktif Pada Perkembangan Ekonomi Syariah di Indonesia

MUI yang berhubungan dengan pasar modal syariah. Tiga (3) fatwa DSNMUI yang menjadi dasar pengembangan pasar modal syariah adalah (Bursa Efek Indonesia, 2018) :

1. Fatwa DSN-MUI No: 20/DSN-MUI/IV/2001 tentang Pedoman Pelaksanaan Investasi Untuk Reksa dana Syariah

2. Fatwa DSN-MUI No: 40/DSN-MUI/X/2003 tentang Pasar Modal dan Pedoman Umum Penerapan Prinsip Syariah di Bidang Pasar Modal

3. Fatwa DSN-MUI No. 80/DSN-MUI/III/2011 tentang Penerapan Prinsip Syariah dalam Mekanisme Perdagangan Efek Bersifat Ekuitas di Pasar Reguler Bursa Efek.

Pasar modal syariah menjadi tren investasi syariah yang diminati masyarakat, secara sederhana pasar modal syariah menerapkan prinsip sesuai syariah dengan tidak melakukan riba, perjudian dan spekulasi (Hana, 2018). Mekanisme penjualan dan pembelian saham syariah harus sesuai dengan syariah, akad yang digunakan dalam pasar modal syariah antara lain ijarah, kafalah, mudharabah, musyarakah, ististna, wakalah (Nafis, 2015).

\section{Wakaf Produktif}

Wakaf produktif merupakan wakaf yang diproduktifkan hasilnya artinya hasil dari wakaf tersebut bisa digunakan untuk kesejehteraan umat wakaf produktif bisa berupa uang atau logam mulia, bangunan (sekolah, rumah sakit mini market dll) dan yang paling baru adalah wakaf saham, berdasarkan penelitian dari Diba anggraini (Nasution \& Aris, 2020) namun di masyarakat luas belum begitu mengenal hal ini di karenakan ada beberapa kendala seperti kurangnya literatur tentang hal tersebut yang berkaitan dengan sosialisasi dan literasi, posisi wakaf dalam ekosistem keuangan syariah masih lemah.

Dengan melakukan wakaf, berarti seseorang telah memindahkan harta dari upaya konsumsi menuju reproduksi dan investasi dalam bentuk modal produktif yang dapat memproduksi dan menghasilkan sesuatu yang bisa dikonsumsi pada masa-masa yang akan datang, baik oleh pribadi maupun kelompok. Dengan demikian wakaf merupakan kegiatan menyimpan dan berinvestasi secara bersamaan. Kegiatan ini mencakup kegiatan menahan harta yang mungkin dimanfaatkan oleh wakif baik secara langsung maupun setelah berubah menjadi barang konsumsi, sehingga tidak dikonsumsi saat ini, dan pada saat yang bersamaan ia telah mengubah pengelolaan harta menjadi investasi yang bertujuan untuk meningkatkan jumlah harta produktif (A. Hakim, 2010) .

Saat ini instrumen filantropi Islam berupa wakaf produktif terus berkembang di Indonesia. Beragam model wakaf produktif terus ditawarkan ke masyarakat. Dan sekarang ini telah muncul model wakaf produktif baru yang sangat potensial, yaitu wakaf saham. Dimana pada 
masa milenial ini dan kemudahan teknologi yang ada serta adanya kemudahan yang telah diberikan maka semakin banyak masyarakat yang memutar harta yang dimiliki kepada membeli surat berharga yang ditawarkan perusahaan melalui bursa efek. Maka dari itu diperlukanlah aturan aturan maupun kebijakan untuk melegalkan pemanfaatan dalam point manfaat saham syariah untuk menjadikannya sebagai instrument utama dimasa dewasa ini untuk kemaslahatan umat dimasa yang akan datang. Wakaf yang menjadi penggerak untuk memajukan umat dari ketertinggalannya sangat dibutuhkan oleh masyarakatnya sementara itu dalam perjalanannya wakaf memerlukan pendukung dalam hal ini adalah dana segar sebagai penggeraknya. Jika menggabungkan dengannya infak, maka dana tersebut akan habis ketika sudah terpakai. Maka sebagai solusi darinya hadirlah instrument pendukung wakaf salah satunya adalah wakaf manfaat saham syariah (M. L. K. Al Hakim, 2019).

\section{Wakaf Saham}

Jenis wakaf itu banyak sekali salah satunya adalah wakaf saham dengan segala kelebihan dan kekurangannya masih perlu memerlukan perbaikan karena masih banya permasalahan yang ada di dalamnya mengenai proses dan sistemnya serta manfaatnya antara realita dan teorinya (Al-hakim, 2018).

Sebenarnya wakaf saham dan wakaf uang hampir sama karena objeknya sama-sama yaitu uang, hanya sumber pada wakaf saham berasal dari pengelolaan saham dimana pengelolaanya terbagi dalam wakaf saham yang dikelola oleh lembaga tertentu dan wakaf saham yang diberikan secara perorangan. Ada beberapa regulasi yang menegaskan bahwa saham syariah itu halal, yaitu mekanisme perdagangan efek bersifat ekuitas di pasar reguler bursa efek Indonesia, DSN MUI membuat 14 fatwa mengenai pasar modal syariah dan jenis investasinya sebagai berikut (Selasi, 2018) :

1. Fatwa No. 20/DSN-MUI/IX/2001 tentang Pedoman Pelaksanaan Investasi Untuk Reksa Dana Syariah.

2. Fatwa No. 32/DSN-MUI/IX/2002 tentang Obligasi Syariah.

3. Fatwa No. 33/DSN-MUI/IX/2002 tentang Obligasi Syariah Mudharabah.

4. Fatwa No. 40/DSN-MUI/X/2003 tentang Pasar Modal dan Pedoman Umum Penerapan Prinsip Syariah di Bidang Pasar Modal.

5. Fatwa No. 41/DSN-MUI/III/ 2004 tentang Obligasi Syariah Ijarah.

6. Fatwa No. 59/DSN-MUI/V/2007 tentang Obligasi Syariah Mudharabah Konversi.

7. Fatwa No. 65/DSN-MUI/III/2008 tentang Hak Memesan Efek Terlebih Dahulu (HMETD) Syariah.

8. Fatwa No. 66/DSN-MUI/III/2008 tentang Waran Syariah. 
Wakaf Saham Sebagai Alternatif Wakaf Produktif Pada Perkembangan Ekonomi Syariah di Indonesia

9. Fatwa No. 69/DSN-MUI/VI/2008 tentang Surat Berharga Syariah Negara (SBSN).

10. Fatwa No. 70/DSN-MUI/VI/2008 tentang Metode Penerbitan SBSN.

11. Fatwa No. 71/DSN-MUI/VI/2008 tentang Sale and Lease Back.

12. Fatwa No. 72/DSN-MUI/VI/ 2008 tentang SBSN Ijarah Sale and Lease Back.

13. Fatwa No. 76/DSN-MUI/VI/2010 tentang SBSN Ijarah Asset To Be Leased.

14. Fatwa No. 80/DSN-MUI/III/2011 tentang Penerapan Prinsip Syariah dalam Mekanisme Perdagangan Efek Bersifat Ekuitas di Pasar Reguler Bursa Efek.

Saham merupakan jenis benda bergerak yang dapat diwakafkan menurut UU Wakaf. Penelitian ini membahas wakaf dalam mewujudkan keadilan distribusi ekonomi, pengaturan saham syariah sebagai objek wakaf,dan upaya perlindungan hukum saham syariah sebagai objek wakaf. Metode yang digunakan dalam penelitian ini adalah metode penelitian hukum normatif (legal research) yang dilakukan dengan pendekatan perundang-undangan dan pendekatan konsep keadilan menurut hukum Islam. Berdasarkan hasil penelitian, secara teoritik tujuan wakaf adalah untuk merealisir keadilan sosial (adminekonomisyariah.org, 2017).

Mayoritas ulama telah memperbolehkan berwakaf melalui uang dan saham, dengan berdasar pada prinsip muamalah yaitu semua hal diperbolehkan kecuali ada dalil yang melarang. Hadits yang menjadi dasar hukum wakaf hanya menjelaskan tentang inti kegiatan wakaf, sedangkan detail pelaksanaannya merupakan hasil ijtihad dari para ulama. Secara umum model pengelolaan wakaf uang dan wakaf saham sama yaitu mengumpulkan dana untuk kemudian dikonversikan ke dalam bentuk aset tetap atau diinvestasikan ke dalam instrumen keuangan. Hanya saja dalam pembahasan wakaf saham, sumber dana wakaf secara spesifik berasal dari saham dan pengelolaannya (Paksi, Manzilati, \& Ekawaty, 2018)

Wakaf Saham dan Surat Berharga dapat Anda serahkan kepada Tabung Wakaf Indonesia sebagai niat baik Anda memperoleh amal jariyah. Surat-surat berharga yang dapat Anda wakafkan antara lain (dompet dhuafa, 2017):

- Saham Perusahaan Syariah Terbuka (Terdaftar di Bursa Efek)

- Goodwill Saham Perusahaan Syariah Tertutup

- Sukuk (Obligasi) Syariah

- Sukuk (Obligasi) Retail Syariah

- Deposito Syariah

- Reksadana Syariah

- Wasiat Wakaf dalam Polis Asuransi 
- Wasiat Wakaf dalam Surat Wasiat

Wakaf surat berharga akan dicatat nilai bukunya pada tanggal penyerahan. Pengelolaan wakaf surat berharga yang berbentuk saham dan obligasi terbuka ditujukan untuk memaksimalkan perolehan deviden (bagi hasil), serta pengembangan portofolio untuk menghindari terjadinya aset yang default. Deviden atau bagi hasil yang diperoleh menjadi surplus yang akan didayagunakan untuk program-program sosial sesuai peruntukannya (pendidikan, kesehatan, pemberdayaan).

Benda bergerak selain uang karena peraturan perundang-undangan dapat diwakafkan sepanjang tidak bertentangan dengan prinsip syariah sebagai berikut: 1). Surat berharga yang berupa: Saham; Surat utang negara; Obligasi pada umumnya; dan/atau Surat berharga lainnya yang dapat dinilai dengan uang. 2). Hak atas kekayaan intelektual yang berupa: Hak cipta; Hak merk; Hak paten; Hak desain industri; Hak rahasia dagang; Hak sirkuit terpadu; Hak perlindungan varietas tanaman; dan/atau hak lainnya. (Direktorat Pemberdayaan Wakaf : 2006). 3). Hak atas benda bergerak lainnya yang berupa: Hak sewa, hak pakai dan hak pakai hasil atas benda bergerak; atau Perikatan, tuntutan atas jumlah uang yang dapat ditagih atas benda bergerak (Direktorat Pemberdayaan Wakaf, 2006)

\section{Perkembangan Wakaf Saham di Indonesia}

Bursa Efek Indonesia menargetkan peluncuran wakaf saham akan dilaksanakan pada April 2019. Nantinya, emiten dan investor saham syariah bisa mewakafkan sahamnya lewat anggota bursa syariah.

Direktur BEI Hasan Fawzi mengatakan, pihaknya akan menggandeng Badan Wakaf Indonesia (BWI), yang berperan sebagai lembaga pengelola wakaf saham dan uang (nazhir) yang terdaftar secara resmi, saat ini BEI masih merumuskan mekanisme pengaturan rencana wakaf saham tersebut dengan berbagai pihak terkait. Menurut dia, mekanisme harus dilakukan secara hati-hati, Nanti mungkin ada MoU AB-SOTS dan BWI mekanisme yang mengikat agar semua oihak tak melenceng dan nanti akan kita kenalkan ke OJK (Fawzi, 2019).

Menurut Nicky Hogan, Direktur Bursa Efek Indonesia (Hogan, 2016) dalam acara Silaknas MES (Masyarkat Ekonomi Syariah) menyatakan bahwa wakaf saham dapat dilakukan dengan dua model, yaitu :

1. Wakaf yang bersumber dari keuntungan investor.

2. Wakaf yang menjadikan saham syariah sebagai objek wakaf. 


\section{Bagan 1.}

Model 1 Wakaf yang bersumber dari Keuntungan Investor

Keuntungan (\%)

Penjualan Saham

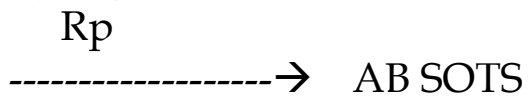

Perjanjian

Investor Syariah $\longleftrightarrow$ Pengelola Wakaf

$$
\downarrow
$$

Aset Wakaf

Sumber ; Model 1 dari Nicky Hogan (2016)

Sumber wakaf yang berasal dari keuntungan investor saham syariah (berupa capital gain atau deviden dan penjualan saham) kemudian dipotong langsung dari keuntungan penjualan tersebut yang melibatkan anggota bursa (AB) syariah online trading system (SOTS) yang merupakan institusi yang melakukan pemotongan keuangan, kemudian keuntungan tersebut akan sisetorkan kepada lembaga pengelola wakaf (misalnya Badan Wakaf Indonesia, dompet dhuafa dll). Setelah keuntungan tersbeut diterima oleh lembaga pengelola wakaf akan mengkonversikan keuntungan tersebut menjadi aset produktif atau langsung dikonversikan menjadi aset sosial (masjid, rumah sakit, sekolah dll).

\section{Bagan 2.}

Model 2 Wakaf yang menjadikan saham syariah sebagai objek wakaf. Lot

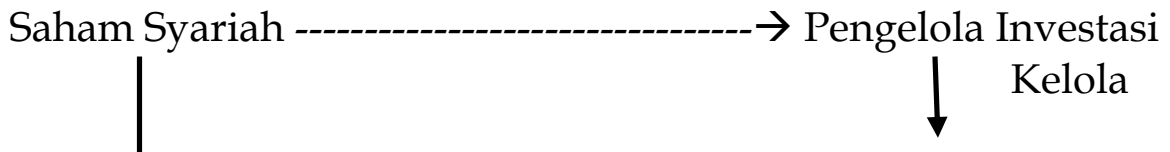

Keuntungan Investasi'

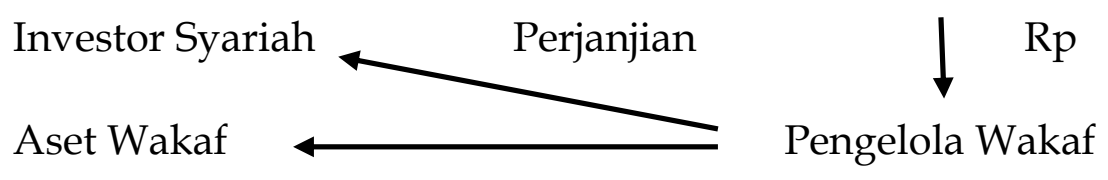

Sumber ; Mode 21 dari Nicky Hogan (2016)

Wakaf saham erat kaitannya dengan pertumbuhan saham syariah artinya jika banyak para investor saham syariah mewakafkan sahamnya atau mewakafkan keuntungan dari penjualan sahamnya maka dengan 
otomatis akan meningkatkan hasil wakaf saham yang akan dikonversikan kepada kegiatan-kegiatan yang dapat mensejahterakan umat, atau bisa disebut dengan wakaf saham sebagai alternatif wakaf produktif. Berdasarkan Keputusan Dewan Komisioner OJK Nomor KEP24/D.04/2018 tentang Daftar Efek Syariah, sebanyak 338 emiten tercatat masuk dalam Daftar Efek Syariah yang dirilis OJK tanggal 24 Mei 2018 (Mang Amsi, 2018)

Berdasarkan penelitian sebelumnya yang dilakukan oleh Indah Yuliana dan Hadi bahwa model wakaf adalah wakaf yang bersumber dari keuntungan investoryang di potong secara langsung dari margin penjualan saham, yang kedua wakaf saham yang dijadikan objeknya adalah saham syariahnya yang melibatkan AB Bursa melalui sistem SOTS dengan prosentase keuntungan yang disisihkan sebagai wakaf yang akan diserahkan pada lembaga pengelolaan wakaf (nadzir) sesuai dengan kesepakatan antara wakif dan nadzir dimana wakaf tersebut akan menjadi aset produktif yang disalurkan untuk kesejahteraan umat (Yuliana \& Hadi, 2019). Pemberdayaan wakaf diperlukan tidak cukup dengan edukasi dan sosialisasi saja melainkan perlu adanya keteladanan dari pemerintah juga (Istikomah, 2019).

Wakaf saham mulai menjadi minat para investor pasar syariah sehingga bisa menjadi penarik bagi emiten yang masuk dalam daftar efek syariah (DES) sehingga para investor dapat berinvestasi dan berwakaf dengan mudah dan fleksibel (Prasetyo, 2019). Berdasarkan penelitian yang dilakukan oleh Frida yustika Rahmat (Rahmat, 2020) melakukan penelitian pada MNC Sekuritas Bandung bahwa pelaksaksanaan wakaf saham sama seperti wakaf pada umumnya, yang diwakafkan merupakan saham syariah yang masuk dalam DES dalam hal ini MNC telah melakukan kebaruan wakaf saham yang sudah dipatuhi semua peraturan, mekanisme serta ketentuan lainnya tidak bertentangan dengan syariah Islam.

Wakaf saham baru dicanangkan pada tahun 2019, diharapkan semua perusahaan sekuritas anggota bursa kedepannya bisa melaksanakan dan memfasilitasi kegiatan wakaf saham, namun ada beberapa yang telah memfasilitasi wakaf saham yang berkerjasama dengan Badan Wakaf Indonesia (BWI) dan Dompet Dhuafa (DD), berikut adalah anggota bursa sharia online trading system (AB-SOTS) yang telah memfasilitasi wakaf saham yaitu (selain memfasilitasi wakaf saham ada pula yang memfasilitsai zakat saham juga ) :

a. PT. MNC Sekuritas

Wakaf saham disalurkan oleh anggota bursa yang mempunyai sistem online trading syariah, salah satunya adalah PT MNC Sekuritas, Direktur Utama MNC Sekuritas Susy Meilina menjelaskan pihaknya berperan sebagai penerima dan perantara wakaf yang diberikan 
investor pasar modal melalui MNC Wakafku kemudian disalurkan kepada badan pengelola wakaf yang telah secara resmi digandeng, yaitu Badan Wakaf Indonesia (BWI), sebagai fasilitator wakaf saham membuka kesempatan bagi perusahaan-perusahaan yang sudah melantai di Bursa Efek Indonesia (BEI) untuk menjadikan sahamnya sebagai wakaf produktif, beberapa perusahaan melakukan penyerahan wakaf, di antaranya PT MNC Kapital Indonesia Tbk yang memberikan wakaf saham senilai Rp 100 juta dan PT Nusantara Sentra Kapital yang memberikan wakaf uang senilai Rp 5 juta. Sebelumnya, PT Hartadinata Abadi Tbk juga telah mewakafkan 100.000 lembar sahamnya melalui MNC Sekuritas (Rahma Diah Setiawan, 2019).

b. PT. Indopremier Sekuritas

Objek wakaf saham dapat berupa saham syariah maupun capital gain serta dividen dari saham syariah yang tercatat di BEI dan masuk ke dalam Indeks Saham Syariah Indonesia ( ISSI ). Pengelola wakaf saham adalah Nazhir yang bekerja sama dengan AB SOTS berperan sebagai wakil investor untuk menyalurkan objek wakaf dari investor ke lembaga pengelola (nazhir). Nazhir merupakan badan hukum yang terdaftar di Badan Wakaf Indonesia (BWI). (IPOTNews, 2019).

c. Philip Sekuritas

Philip Sekuritas bekerjasama dengan Dompet Dhuafa (DD) sedang menjajaki kerjasama dengan Bursa Efek Indonesia (BEI) dan beberapa perusahaan sekuritas. Ini sebagai salah satu upaya penghimpunan dana melalui investasi wakaf saham. Sejumlah perusahaan yang tengah dijajaki tersebut diantaranya Philips Sekuritas, mekanisme dari wakaf saham ini yaitu investor melakukan transaksi wakaf saham dengan perusahaan sekuritas. Perusahaan Sekuritas kemudian mentransfer saham ke rekening efek nazir untuk dikelola, sedangkan saham yang boleh diwakafkan untuk wakaf saham ini adalah saham syariah. Dompet dhuafa baru saja menerima wakaf saham dari Forum Silaturahmi Studi Ekonomi Islam (FoSSEI) sebanyak 19 lot yang ditransfer melalui Philip Sekuritas (Wullandari, 2019).

d. PT Henan Sekuritas

Mohamad Yunus sebagai Direktur Henan Sekuritas dalam acara Talk Show ramadhan dengan tema "Bangkitkan Pasar Modal Syariah" Melaui Zakat \& Donasi Saham yang diselenggarakan oleh Henan Putihrai Sekuritas, Baznas dan Bursa Efek Indonesia. Pasar Modal Syariah sudah harus mulai berinovasi untuk memberikan donasi bantuan melaui zakat. Yang bertujuan untuk membantu meningkatkan perekonomian di indonesia. Diharapkan melalui acara ini peserta talkshow lebih giat lagi dalam berinvestasi di pasar modal 
syariah. Terlebih saat ini sudah ada sekuritas yang menerapkan zakat dan donasi Saham dalam sistem transaksinya (Yunus, 2019).

e. BNI Sekuritas

Pada tahun 2019 meluncurkan BIONS yaitu BNI Sekuritas Innovative Online Trading System dengan menggunakan aplikasi tersebut BNI sekuritas bisa melakuka transaksi wakaf saham. wakaf saham adalah menyumbangkan sebagian saham yang dimiliki investor utuk dikelola oleh nadzir yang disalurkan melalui Global Wakaf. BNI Sekuritas sudah mengelola wakaf melalui global wakaf dengan 5 lot ANTM, 5 lot EXCL, 5 lot JSMR, 5 lot WIKA, 1 lot BTPS dan 1 lot KLBF (luthfi, 2020)

\section{KESIMPULAN}

Salah satu bentuk bentuk dari filantropi Islam adalah wakaf, salah satunya adalah wakaf produktif merupakan wakaf yang bisa dimanfaatkan untuk kesejahteraan umat. Wakaf saham salah satu jenis dari wakaf produktif, dengan wakifnya para investor saham syariah sementara yang menjadi objek atau mauqif adalah saham syariah yang masuk dalam daftar DES dan nadzirnya atau yang mengelola wakaf saham BWI atau dompet dhuafa yang akan menyalurkan pada mauquf 'alaihi sebagai penerima manfaat mauqif.

\section{DAFTAR PUSTAKA}

Abdalloh, I. (2018). Pasar Modal Syariah. Jakarta: PT Elex Komputindo. adminekonomisyariah.org. (2017). Saham Syariah sebagai Objek Wakaf Setelah berlakunya Undang-Undang Nomor 41 Tahun 2004 tentang Wakaf.

Ahyudin. (2017). Forum Bisnis Wakaf Ajak Perusahaan Wakaf Saham.

Al-hakim, M. L. K. (2018). Wakaf Manfaat Saham Syariah untuk Kemaslahatan. Al-Awqaf: Jurnal Wakaf Dan Ekonomi Islam, 11(1), 89100.

Al Hakim, M. L. K. (2019). Wakaf Manfaat Saham Syariah untuk Kemashlahatan.

Bursa Efek Indonesia. (2018). Fatwa dan Regulasi Pasar Modal Syariah.

Creswell, J. (2018). Five Qualitative Approaches to Inquiry. England: Sage Publication, Inc.

Direktorat Pemberdayaan Wakaf. (2006). Bunga Rampai Perwakafan. Jakarta, Indonesia: Departemen Agama. dompet dhuafa. (2017). Surat Berharga yang Dapat Diwakafkan. Fawzi, H. (2019). BEI Targetkan Wakaf Saham Diluncurkan Pada April 
Wakaf Saham Sebagai Alternatif Wakaf Produktif Pada Perkembangan Ekonomi Syariah di Indonesia

2019.

Hakim, A. (2010). Manajemen Harta Wakaf Produktif dan Investasi Dalam Sistem Ekonomi Syari'ah. Jurnal Riptek, 4(2), 1-62.

Hana, K. F. (2018). Dialektika Hukum Trading Saham Syariah di Bursa Efek Indonesia. Tawazun: Journal of Sharia Economic Law, 1(2), 148-160. Retrieved from http://journal.stainkudus.ac.id/index.php/tawazun/index

Hana, K. F. (2019). Efektifitas Literasi Melalui Game Nabung Saham Go Terhadap Keputusan Membeli Saham Syariah. EQUILIBRIUM: Jurnal Ekonomi Syariah, 7(2), 367-385. Retrieved from journal.stainkudus.ac.id/index.php/equilibrium\%0AEfektifitas

Hanna, S. (2015). Wakaf Saham dalam Perspektif Islam. Mirzan Jurnal Ilmu Syariah, 3 no.1 Jun, 99-124.

Hogan, N. (2016). Wakaf Saham; Alternatif model wakaf produktif.

IPOTNews. (2019). Indo Premier Siap Fasilitasi Program Wakaf.

Istikomah, I. (2019). Penguatan Sektor Pertanian Melalui Bank Wakaf Tani Berbasis Mudharabah. TAWAZUN: Journal of Sharia Economic Law, 2(2), 135-146.

luthfi. (2020). Webinar Wakaf Saham. Jakarta.

Mang Amsi. (2018). 358 Emiten Masuk DES Periode Juni-November 2018.

mysharing.co. (2017). Jenis Wakaf Produktif Yang Dapat Mengembalikan Kejayaan Umat Muslim.

Nafis, A. W. (2015). Akad-akad di Dalam Pasar Modal Syariah. Iqtishoduna J. Ekon. Islam, 5(1), 66-86.

Nasution, L. Z., \& Aris, D. A. (2020). Konstruksi Pengembangan Wakaf Saham Dalam Rangka Mengoptimalkan Potensi Wakaf Produktif di Indonesia. Islamic Circle, 1(1), 27-52.

Paksi, G. M., Manzilati, A., \& Ekawaty, M. (2018). Kajian Hukum dan Implementasi Wakaf Harta Bergerak di Indonesia: Wakaf Uang dan Saham. ISLAMICONOMIC: Jurnal Ekonomi Islam, 9(2).

Prasetyo, A. (2019). Wakaf Saham Dalam Meningkatkan Investasi Saham Syariah Di Indonesia. Majalah Ekonomi, 24(2), 204-210. https:/ / doi.org/10.36456/majeko.vol24.no2.a2066

Purnomo, S. (2019). Inilah Dalil Disyariatkannya Berwakaf.

Rahma Diah Setiawan, S. (2019, May). Tak Hanya Tanah, Kini Saham Juga Bisa Diwakafkan. Kompas.Com.

Rahmat, F. Y. (2020). Tinjauan hukum ekonomi syariah pada pelaksanaan wakaf saham di PT MNC Sekuritas Bandung. UIN Sunan Gunung Djati Bandung.

Ridwan, M. (2018). Fleksibelitas Hukum Ekonomi Syariah. TAWAZUN: Journal of Sharia Economic Law, 1(2), 161-173.

Sahroni, O. (2018, November). Konsultasi Syariah: Wakaf Saham. Republika.Co.Id. 
Selasi, D. (2018). Ekonomi Islam; Halal dan Haramnya Berinvestasi Saham Syaria. Jurnal Ekonomi Syariah Dan Bisnis, 1(2), 87-96.

Teguh Saptono, I. (2019). Wakaf Saham.

Ulinnuha, M., Susilowati, D. E., \& Hana, K. F. (2020). Persepsi Investor Pemula Terhadap Pembelian Saham Syariah di Indonesia. Jurnal Ilmu Ekonomi Dan Bisnis Islam, 2(1), 1-14. https:/ / doi.org/10.24239/jiebi.v2i1.20.1-14

Wullandari, R. (2019, May). Incar Wakaf Saham, Dompet Dhuafa Jajaki Perusahaan Sekuritas. Republika.Co.Id.

Yuliana, I., \& Hadi, S. P. (2019). Model Penerapan Dan Potensi Wakaf Saham Di Indonesia. Jurnal Perspektif Ekonomi Darussalam, 5(2), 227239.

Yunus, M. (2019). Bangkitkan Pasar Modal Syariah Melalui Zakat dan Donasi Saham. 